\section{Thoughts for the internationalization of SMES in Ecuador and its institutional framework}

Reflexiones para la internacionalización de las PYME en Ecuador y su entorno institucional

\author{
Rubén Méndez Reátegui; Fernanda Macías Mero
}

\begin{abstract}
Due to their employment and the national GDP, SMEs' relevance generates interest in promoting their growth through internationalization. From this scenario, its business structure is an advantage for internationalization, allowing greater adaptability to change. Through the Neo Institutional analysis, this research highlights the need to study the game rules that can affect SMEs as an essential factor for developing internationalization as a growth strategy based on the importance of institutions (formal and informal rules of the game) as part of that environment. The result of the investigation points to the conclusion that there would be a strong influence of the institutional environment or framework of the rules of the game in the low levels of internationalization of Ecuadorian SMEs. Therefore, it is necessary to promote actions that improve the said environment (an institutional amalgam of SMEs) and thereby reduce the transaction costs present in the internationalization process and promote a collaborative institutional environment that favors the appearance of incentives that positively affect the business climate for SMEs and, therefore, in their systemic competitiveness.
\end{abstract}

Keywords: Institutionalization; business; legal system; international economic relations; economic growth

\section{RESUMEN}

La trascendencia que poseen las PYME producto de su participación en el empleo y el PIB nacional genera interés en promover su crecimiento a través de la internacionalización. A partir de ese escenario, su estructura empresarial es vista como una ventaja para la internacionalización, en tanto, le permite mayor adaptabilidad al cambio. A través del análisis Neo Institucional esta investigación destaca la necesidad de estudiar el entorno de reglas de juego (formales) que puede incidir sobre las PYME como factor de importancia para el desarrollo de la internacionalización como estrategia de crecimiento. El resultado de la investigación apunta a concluir que existiría una fuerte influencia del entorno institucional en los bajos niveles de internacionalización de las PYME ecuatorianas. Por lo tanto, resulta necesario impulsar acciones que mejoren dicho entorno (amalgama institucional) y con ello reduzcan los costos de transacción que favorezca la aparición de incentivos que incidan positivamente en el clima de negocios para la PYME y, en consecuencia, en su competitividad sistémica.

Palabras clave: Institucionalización; empresa; sistema legal; relaciones económicas internacionales; crecimiento económico

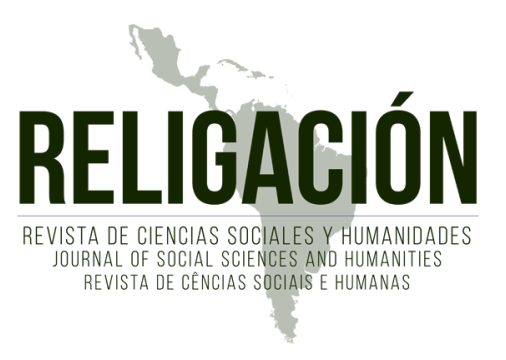

ARTICLE INFORMATION:

http://doi.org/10.46652/rgn.v6izo.835

ISSN 2477-9083

Vol. 6 No. 30, 2021. e210835

Quito, Ecuador

Submitted: 27 August 2021

Accepted: 13 October 2021

Published: 30 October 2021

Continuous Publication

South-South Section | Peer Reviewed

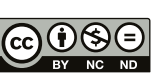

\section{open 2 access}

\section{AUTHORS:}

Rubén Méndez Reátegui

Pontificia Universidad Católica del Ecuador - Ecuador

rcmendez@puce.edu.ec

(D) Fernanda Macías Mero

Grupo de Investigación en Derecho Económico - Ecuador gide@puce.edu.ec

\section{CONFLICT OF INTEREST}

No potential conflict of interest is reported by the authors.

FUNDING

No financial assistance from parties external to this article.

ACKNOWLEDGMENTS $N / A$

ENTIDAD EDITORA

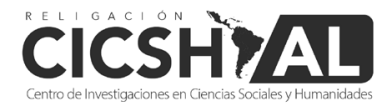




\section{Introduction}

Globalization as a worldwide economic phenomenon generates significant transformations in business schemes aimed at increasing the levels of performance and efficiency to face the scenarios of increased competition in the global environment (Vargas et al., 2011, p. 121). It highlights the importance of developing advantages that strengthen the participation of the different economies in the international market; however, this level of participation is limited, as Oiso (2005) explains, by its position in the international hierarchy.

Furthermore, and given the need for a more significant presence of developing countries within the global economy, in recent years, the study of the phenomenon of Small and Medium Enterprises (SMEs) and their projection towards international markets has intensified, supported by the great importance that this sector represents for the domestic economy of countries, especially for its direct impact on job creation and its participation in the gross domestic product (GDP) of the countries (Rojas and Vega, 2013, p. 55).

Contemporary literature related to the study of SMEs has recurrently argued that the lack of business culture, untrained personnel to carry out international processes, the lack of resources, and the lack of (efficient) government support are the main limitations for the insertion of SMEs in the international arena (Vargas et al., 2011, p. 121). Without detracting from these positions, it is worth considering that the core generator of these factors is the institutional structure of a country, meanwhile, as Alonso points out, there is "a close relationship between the conditions of the national environment and the competitive possibilities of the company" (2012, p. 65), since the environment of rules of the game influences the latter from its conception.

Furthermore, Baumol (1990) explains that the different institutional environments provide the framework under which the various types of entrepreneurship are developed. It is relevant since institutions act through formal incentives or regulations, which entrepreneurs will measure. They will choose the type of entrepreneurship they will carry out, whether productive or unproductive, considering the benefits and rewards of the institutional framework.

Moreover, this article will discuss the following preliminary assessment: internationalization management institutions' influence as a growth strategy for SMEs.

Considering institutions as "the rules of the game in a society or, more formally, the constraints or obligations (...) that shape human interaction" (North, 1990, p. 3); and since that the company is conditioned by both the national and international environment in which it operates (Alonso, 2012, p. 65). It is then assumed that the greater the balance in the SME - institutional framework relationship, the more effective internationalization management is. However, it is necessary to clarify that this contribution will not propose a study along the lines of the classical understanding of fields of study such as traditional economic law or even regulatory law. Its purpose, less ambitious, is to introduce a reflective and descriptive study inspired by the Comparative Institutional Analysis proposed by the late Stanford University professor Masahiko Aoki (2001) in his Toward a Comparative Institutional Analysis. Because, "the wide-ranging discussion considers how institutions evolve, why their overall arrangements are robust and diverse across economies, and why they do or do not change in response to environmental factors such as technological progress, global market integration, and demographic change" (Aoki, 2001, p. 34)

The primary purpose of this is to describe -mainly- the performance or manifestation of specific agents subject to previously established rules of the game or institutions in force. It is taken for 
granted, then, that these per se affect the conduct of entrepreneurs and microeconomic agents known as SMEs. Moreover, without intending to introduce a specific proposal for reforming the current regulatory framework, the article will start from the following assumption: the suboptimal and perfectible nature of the prevailing rules.

\section{Methodology}

The article proposes a conceptual, theoretical analysis to strengthen future strategies for the internationalization of Ecuadorian SMEs.

Due to the objective of this contribution, the qualitative approach presents the ideal framework that allows, on the one hand, to delve deeper into the existing theory concerning the topic in question and, on the other hand, to review Ecuadorian SMEs concerning internationalization, since, as Blasco and Pérez state, qualitative research studies reality from its natural context (2007, p. 17). Furthermore, the use of qualitative research through the proposed techniques responds to the need to investigate social and organizational behaviours that explain the effects of the interaction of the different economic, political, and social agents involved in internationalization processes, hence the importance of using tools that allow greater freedom during the information gathering process.

Likewise, the method will be a structural part of this article, characterized as systemic, rational, and critical (Hernández et. al., 2010). The proposed qualitative methodology will allow us to outline the path to follow to achieve the proposed objective. Therefore, it will involve the following cognitive processes:

a) The separate evaluation of the different factors to obtain general conclusions regarding our thematic proposal, i.e., to gather a general framework on Ecuadorian SMEs' internationalization process through the actors' characterization.

b) The use of relevant chronological information to know its evolution and development over time, so its use in the article is linked to robust support on small and medium-sized enterprises' internationalization process.

c) The analysis of different phenomena within the whole will involve a detailed review of each of these singularities to understand their relationship in the quest to discern elementary issues of SME internationalization.

In terms of research levels, this contribution has an explanatory-descriptive character. In other words, our contribution aims to provide solid support for the existing interaction between the different actors involved in the internationalization processes of SMEs, specifically in the city of Quito, to find the factors that have the most significant influence on internationalization processes and that can be modified or made more efficient in order to offer more significant benefits than those currently provided. It is also essential to explore concepts related to internationalization processes and strategies used worldwide to obtain a broader spectrum on which to base the proposal for an internationalization strategy for SMEs in the city of Quito. 


\section{Data collection and processing}

\subsection{Internationalization and SMES}

The changes in business schemes caused mainly by globalization (Vargas et. al., 2011, p. 121) influence companies' need to adopt new growth processes to achieve more remarkable business development (Poblete and Amorós, 2013, p. 99). This process is not alien to SMEs, as among their primary purposes is the accelerated search for growth. However, when we refer to internationalization as a means of growth, we find a comprehensive debate between those who claim that this process is exclusive to large companies with extensive experience and support; and those who argue that internationalization applies to small companies with the ability to adapt to the environment.

In the first group, we find authors such as Gandoy et al., who consider that exporting companies generally have characteristics -some of them foreign to SMEs- among which are: larger size, higher productivity, more intensive in human physical capital and more innovative (2014, p. 132). For their part, Esteve and Rodríguez (2014) stress that among the main barriers faced by SMEs given their smaller size are the difficulty of covering irrecoverable costs, poor access to financial resources and deficiencies in their skills, which make them unsuitable companies to take on the challenge of internationalization (p. 116). BarNir et al. (2003); Gabrielsson et al. (2008); associate the inability of SMEs to internationalize to their difficulties to create competitive advantages through the generation of economies of scale, as well as to make a good market exploration, in addition to the fact that they have few resources to ensure good positioning.

In the second group, authors such as Majocchi and Zucchella (2003) explain "that business size does not always determine international competitiveness" (Cambra and Vázquez, 2010, p. 64), according to these authors, SMEs, regardless of their smaller size, have factors such as greater flexibility and an innate stimulus to grow, which facilitates and accelerates their adaptation to international markets, with the additional advantage that sales figures in the international sphere exceed those achieved in local or national markets, generally mature and saturated, where the only way to grow is through internationalization (Kalantaridis, 2004) (cited by Cambra and Vázquez, 2010, p. 64).

Internationalization as a growth strategy is one of the most complex and challenging decisions to make. It involves a scenario of high competition, faster forms of communication and transport, the use of technologies that make it possible to reduce costs and, in some cases, eliminate borders, shorten distances and make the business world increasingly smaller and more accessible (Delgadillo de Lira, 2004, p. 92), necessarily involves using tangible and intangible resources and analyzing the firm's capabilities and skills as it seeks to take its first steps in a global environment (Campins, 2015, p. 97).

Notwithstanding the difficulties that this process poses, we consider it viable for a small company to move into foreign markets if it has the necessary tools that allow it to develop within this highly competitive framework. In addition to an internal structure, these tools include supporting a cooperative institutional framework for this purpose.

Thus, faced with an internal assessment of whether the SME can support an internationalization process, i.e., on the one hand, it has strengths such as highly qualified and experienced staff, favorable management attitudes towards doing business in foreign markets, or the possibility that 
the product will be better appreciated or paid in the foreign market. On the other hand, with the impetus of a foreign market that offers the benefits of free trade agreements, higher profitability, the realization of economies of scale, or the exploitation of tax advantages or cheaper labor (Cantarero and Puig, 2013, p. 35). It is also necessary to assess whether the environment offers the necessary incentives.

Furthermore, the involvement of public institutions that promote international competitiveness is a determining factor in the international performance of companies, especially if it is complemented by factors such as access to capital, risk-taking strategies and the ability to cooperate and learn through business networks, as these tools help rapid and sustainable internationalization (Amal and Rocha, 2010) (cited by Rojas and Vega, 2013, p. 60). The challenge is to develop enabling environments and critical institutions within economies that foster the factors mentioned above' emergence.

\subsection{Determinants of the internationalization process}

Faced with the complex scenario posed by internationalization, it is essential to point out the determining aspects that support or limit the internationalization process, specifically those that involve the structure of the company.

Based on studies by several authors including Velasco and López (2003); León, (2008); Escolano and Belso (2003); Poblete and Amorós (2013); Botello (2014); Pla and Cobos (2002) and Llonch (2006). The main determinants that act favorably or unfavorably with the objective of SME internationalization are detailed below.

\subsubsection{Human capital}

They start from the fact that human resources are vital for the proper functioning of a company, especially given the current "complexity of the global economy" (Tabares, 2012, p. 12) and the rapid evolution of the current market (Olivares, 2005, p. 129). It is no different when we talk about internationalization; the firm's manager's and employees' academic training is a critical factor among exporting companies and international networks (Gandoy et al., 2014, p. 142).

According to Tabares, the arrival in specific sectors and their permanence result from the decisions made by the highest link in the business structure; and subordinates' ability to adopt these decisions on their own (emphasis added) (2012, p. 12). Consequently, managerial skills and the insights gained from the environment are considered by Manolova, Brush, Edelman, and Greene (2002, p. 9) as the most critical dimensions of the human capital of an SME.

There is also a meaningful relationship between a higher qualification of human resources in exporting companies and innovative capacity, resulting in the production of high-quality goods and services (Bernard et al., 2012), which represent an essential competitive advantage for SMEs, even more so considering the limitations of this type of business structures (Gandoy et al. 2014, p. 142).

Moreover, barriers to Innovation "are not the same for every company; Barriers can be expected to differ, for example, according to the size of the company, the line of the industry and the degree of innovation of the Company" (Benavides and Bolaños, 2020, p. 224).

This is why the importance of the internationalization of SMEs is pointed out, considering that in a comparative study carried out in European countries, which had as a result: 
A comparative study of the innovation barriers of European SMEs found that the main difficulties faced by the participants are: the dynamics of the current economy, the limitation of monetary resources, mechanical returns, routine and established processes, organizational resources, the resistance to change of human resources, the lack of incentives and compensation for innovation, the high cost of new tools, the small size of the companies and the leadership and risk-taking profile of the owner. (Cordeiro and Vieira, 2012) (cited by Benavides and Bolaños, 2020, p. 230) (emphasis added)

In Ecuador, the valuation of human resources to improve the innovative capacity of SMEs is still in process. Moreover, the institutions that support SMEs play an important role in supporting the internationalization process. However, considering that human capital is the main manager of the correct performance of each stage of the production and internationalization process, it is necessary that both policies and government organizations coordinate actions in order to promote the better performance of human resources (Cando, López and Zambrano, 2019, p. 485).

For this reason, Merino et al. (2017) considers those gains from competitiveness to have three pillars:

a) Investment in research and technological development (R\&D);

b) The enhancement of qualified human capital; and,

c) The existence of a business sector that absorbs knowledge and technology to promote new products and services. (p. 23)

\subsubsection{Innovation}

The globalization of markets has accentuated the role those economic agents assign to innovative management as the main generators of greater competitiveness (Yoguel and Boscherini, 1996, p. 95), to the point of considering that companies that do not innovate at the end will die, since, over time, products and processes have a shorter useful life (Escorsa and Valls, 2003, p. 15). Consequently, the innovative activity must be understood as a fundamental strategy for companies; and its application must be carried out in a structured, organized, and systemic way, in such a way that it has a substantial impact on the increase of the company's competitive capabilities and becomes a central part of the overall business strategy (Lawson and Samson, 2001) (cited by Vargas et al. 2011, p. 124).

Activities that are projected to increase firms' innovativeness are developing and improving products and processes, implementing organizational changes and new forms of market linkages, and implementing quality management systems (Moori et al., 2001). Innovation, therefore, "implies changes that can be gradual or radical, in an established direction or a different direction" (Vargas et al., 2011, p. 124).

The relevance that innovation assumes within the internationalization processes is not in doubt. However, sometimes its implementation as a competitiveness strategy is complex due to the existence of barriers, which are classified by Vargas et al. through macro and microeconomic factors, among the macroeconomic barriers (of the environment) (2011, p. 124). Here, we find the existence of excessive regulations, the lack of a favorable technological environment, the lack of support, the shortage of inputs, the lack of adequate financing, among the most important. In contrast, the microeconomic ones are composed of factors such as the lack of business skills, technical knowledge, qualified human resources, and negative organizational cultures' prevalence to change, which is a more significant presence among SMEs. 
Innovation through investment in R\&D, especially in SMEs, should be explored independently for each sector of activity to which small and medium-sized enterprises belong, including the suitability between in-house technology development or outsourcing. However, the most important thing for SMEs to consider is that innovation is the primary resource for improving competitiveness. Therefore, regardless of the environment, its acquisition is necessary, and how to optimize it is a task of shared responsibility between management and their partners.

According to information presented by the PyME's Observatory of the Universidad Andina Simón Bolívar, Ecuador (2012), Ecuadorian SMEs have successfully entered international markets in terms of innovation markets made innovations basically to their products, processes, internal organization and machinery and equipment. However, the last National Economic Census of 2010 shows through its results that the execution of tasks related to research and development is still pending among the majority of Ecuadorian SMEs, as only $12 \%$ of small and medium-sized exporting companies allocate resources from their budgets for this task (Araque and Argüello, 2015, p. 43).

\subsubsection{Cooperation}

The existence of a "greater interrelation and integration of markets on a global scale" (Mínguez, 2010, p. 113) not only forces to rethink innovation processes in companies but also adds "new agents and operational forms" (Bellini, Toscana, Villarreal and Klappenbach, 2015, p. 87) that will be part of the emergence of cooperation agreements. In general terms, business cooperation for internationalization refers to an "agreement established between two or more companies to share resources, capabilities, efforts, risks, responsibilities and potential benefits in accessing foreign markets" (Mínguez, 2010, p. 114).

Cooperation agreements are an excellent option, especially for SMEs with lower export intensity, as the connections with companies in the destination country facilitate the distribution of their products under better conditions and, therefore, improve their competitiveness (Estrella et al., 2012, p. 97). The main advantages that cooperation allows for SMEs -even more so when their objective is internationalization- are the improvement in their levels of competitiveness, the reduction of uncertainty and therefore of the risk generated by foreign markets, as well as the reduction of transaction costs, which include the cost of accessing markets, information costs and technology acquisition costs, the exploitation of synergies through the combination of experiences and the complementarity of resources that favours the generation and exploitation of economies of scale (Mínguez, 2010, p. 114).

On the other hand, the complications they face include new transaction costs related to the management, information, coordination and control of the cooperation agreement, complexity, legal restrictions, cultural obstacles (language, forms of organization of societies), as well as the necessary loss of strategic autonomy among partners (Mínguez, 2010, p. 114).

Whether or not to opt for business-to-business cooperation should be a well-thought-out decision. Factors such as the most appropriate type of cooperation, or the costs that are reduced versus those that arise, will make it possible to discern whether internationalization through business cooperation is feasible under the current conditions.

Cooperation between different actors in a productive sector is undoubtedly a valuable tool for obtaining competitive advantages (Mesa and Pérez, 2011). Therefore, when we refer to establishing spaces for cooperation between international companies, this advantage becomes even more 
valuable, in terms of the positive effects it will produce during an internationalization process. However, in order to achieve alliances of this type with companies abroad, the institutional environment must provide secure conditions, i.e., there must be an environment that guarantees that by adopting this growth strategy, both parties will benefit equally, otherwise these processes will not be successful. In Ecuador, cooperation processes are mostly internal; there is a high propensity among SMEs to join trade associations (Araque and Argüelo, 2015).

\subsection{Export capacity of Ecuadorian SMEs}

It is common to review figures that show internationalization processes of large companies, with an extensive and solid internal track record that in one way or another supports the decision to initiate an internationalization process. However, these figures are reduced when we talk about developing economies -such as the Ecuadorian economy- characterized by a smaller number of large companies and a small and medium-sized enterprise sector that is constantly growing. In this context of broad SME participation in the domestic economy, it is only logical to consider this sector's growth through access to foreign markets.

Based on statistics from INEC in 2019, in Ecuador, micro-enterprises represent $90.89 \%$ of the total number of enterprises, SMEs $8.62 \%$ and large enterprises only $0.49 \%$ (INEC, 2020). Paradoxically, companies' orientation towards foreign markets increases as their size increases (Figure 1), i.e., the export trend of small and medium-sized companies is historically lower than that of large companies (Araque et al., 2015, p. 39).

Figure 1: Exporting and non-exporting companies by size

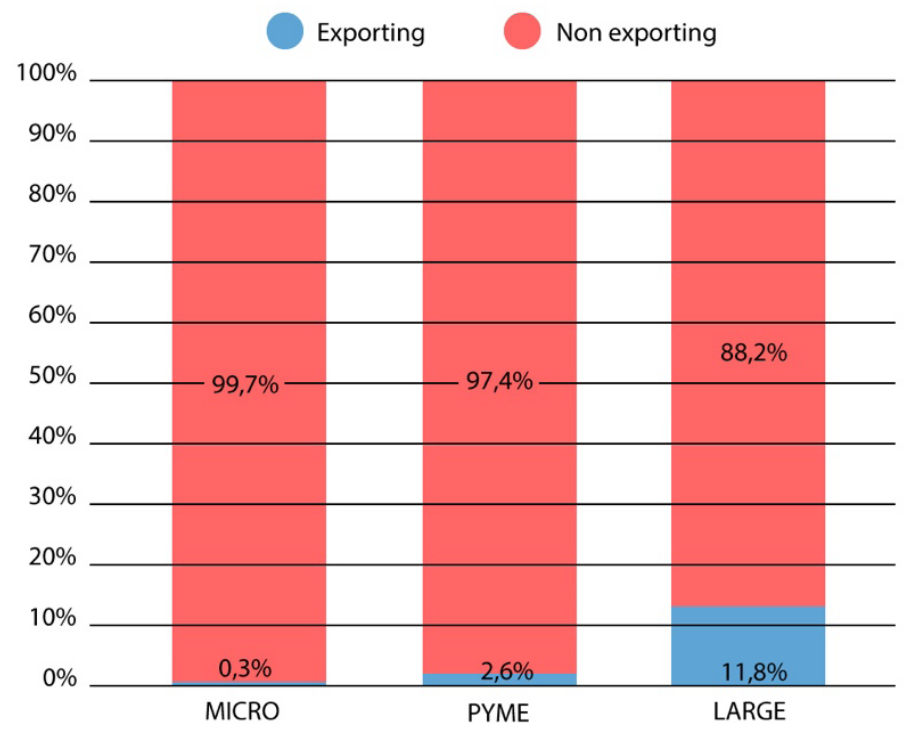

Source: Own elaboration. PYME’s Observatory of the Universidad Andina Simón Bolívar, Sede Ecuador (2012, n. p.).

More recent figures show an increase in the participation of Ecuadorian SMEs in the Ecuadorian export sector: between January and July 2018, non-oil exports registered an FOB amount of $\$ 7,761.5$ million (Dirección de Inteligencia de Negocios, 2019), of which $\$ 2,672$ million corresponded to SME exports (El Telégrafo, 2019), representing 34.4\%. However, in the same period of 2019 the share of SMEs in trade decreased by $\$ 328$ million (El Telégrafo, 2019) despite total exports growing by $4.1 \%$ (Dirección de Inteligencia de Negocios, 2019). 


\subsection{The influence of the institutional environment on the internationalization process}

For years, the importance of variables related to the company's internal structure -qualified personnel, research in innovation and development, generation of economies of scale, has been highlighted as the main determinants in a company's decision to internationalize. However, it is necessary to review how and to what extent state institutions influence this process.

The state intervenes in all aspects of a society's coexistence. The neo-institutional analysis highlights the importance of state institutions as structures capable of stimulating cooperation between the individuals through incentives and generating compelling dynamism between state and society (Jaime et al., 2013, p. 17). However, in practice, achieving adequate understanding between the state and society is limited by the correspondence that one of the parties' actions have with the other's objectives. Since, as Jaime et al. mention, one can tend to forget the unequal character that the rules of the game can sometimes adopt, which breaks the harmony of the system, since what one of the parties adopts as a practical action may not be seen from the same perspective by the other party (2013, p. 17).

The business environment is consequently delineated by the interrelation of the set of institutions and economic actors of a country, which, if clear, shared and efficient rules are established, can generate what Camagni (1991) and Bianchi and Miller (1994) call competitive advantages for companies (Yoguel, 1998, p. 13). Therefore, the government's role includes shaping quality institutions, which regulate and steer society efficiently.

Public policies are one of the main mechanisms of state influence, and their review is crucial in the field of internationalization. The different incentives that public policies create will determine the quality and quantity of internationalization (Finchelstein, 2013). An SME that considers internationalization as a growth strategy needs an environment of clear rules to support its objective. SMEs require sustainable, credible, consistent and intertemporally coherent public policies to send the right signals to companies (Finchelstein, 2013).

This stage of correspondence between the state and business is established based on quality institutional system, which includes coherent public policies and an ideal bureaucracy, which according to Evans (1995), is autonomous concerning sectoral and coalitional interests but at the same time close to the needs of all actors. Regarding the importance of efficient institutional systems, (Alonso and Garcimartín, 2008, p. 115) detail the dimensions that form part of the measurement of the quality of institutions linked to government performance:
a) Political stability
b) Rule of law (Méndez and Sumar, 2020, p. 377)
c) Efficiency in public management
d) Controlling corruption
e) The government's capacity to develop and implement policies
f) The efficiency of distributive policies
g) The citizens' participation and the government accountability.

Ecuador has a wide gap in terms of institutional quality. International measurements, such as the Institutional Quality Index report, highlight the poor performance of Ecuador, which year, after year has occupied the worst-performing positions, mainly in its political and economic institutions, for example, in 2019 Ecuador, was ranked 142nd (Krause, 2019); However, the current 129th position does not necessarily imply that the quality of Ecuador's political and market 
institutions reaches the level of efficiency necessary to provide stability and efficiency in public management.

According to Keefer and Knack (1995), Rubio (1998) and Hernando de Soto (1997), the economic growth of countries is subject to the quality of their institutions; therefore, given this scenario, it is understandable that Ecuadorian SMEs discard the option of internationalization as a growth strategy since they must deal with an inefficient institutional environment.

For example, countries such as Brazil and Chile have sought to issue public policies such as creating credit lines, technical assistance, and tax incentives, creating new opportunities to encourage companies' international expansion, and achieving good results (Finchelstein, 2013). On the other hand, in Ecuador, to function correctly, companies must comply with more and more requirements, mainly tax ones (see Table 1).

Table 1: Taxes and Obligations for Ecuadorian Companies

\begin{tabular}{|c|c|}
\hline \multicolumn{2}{|c|}{ TAXES } \\
\hline Tax detail & Institution \\
\hline Declaration of Value Added Tax (VAT) & Servicio de Rentas Internas (SRI) \\
\hline Income Tax Declaration & Servicio de Rentas Internas (SRI) \\
\hline Payment of the advance payment of income tax. & Servicio de Rentas Internas (SRI) \\
\hline Declaration of Special Consumption Tax (ICE) & Servicio de Rentas Internas (SRI) \\
\hline $\begin{array}{l}\text { Annex of withholdings at the source of Income Tax } \\
\text { for other concepts (REOC) }\end{array}$ & Servicio de Rentas Internas (SRI) \\
\hline Simplified Transactional Annex (ATS) & Servicio de Rentas Internas (SRI) \\
\hline $\begin{array}{l}\text { Annex of Income Tax in relation to dependency } \\
\text { (RDEP). }\end{array}$ & Servicio de Rentas Internas (SRI) \\
\hline ICE Annex & Servicio de Rentas Internas (SRI) \\
\hline $\begin{array}{c}\text { Property Tax on Land and Cargo Transportation } \\
\text { Vehicles. }\end{array}$ & Servicio de Rentas Internas (SRI) \\
\hline Assets Declaration Annex & Servicio de Rentas Internas (SRI) \\
\hline Annex International Currency Movement & Servicio de Rentas Internas (SRI) \\
\hline $\begin{array}{c}\text { Annex Notaries, Property Registrars and Mercantile } \\
\text { Registrars (ANR) }\end{array}$ & Servicio de Rentas Internas (SRI) \\
\hline $\begin{array}{l}\text { Annex of Operations with Related Parties Abroad } \\
\text { (PRE) }\end{array}$ & Servicio de Rentas Internas (SRI) \\
\hline Municipal Patent & Municipality \\
\hline
\end{tabular}

OBLIGATIONS

Employer contribution to the IESS for each employee Instituto Ecuatoriano de Seguridad Social (IESS)

Reserve funds

\begin{tabular}{cc}
\hline \multicolumn{1}{c}{ FORMS } \\
\hline $\begin{array}{c}\text { Balance sheets (Form 101) submit in the first quarter } \\
\text { of each year }\end{array}$ & Superintendencia de Compañias \\
\hline $\begin{array}{c}\text { Unique data update form (List of shareholders) } \\
\text { List of Administrators or Legal Representatives } \\
\text { Report or memory presented by the Legal } \\
\text { Reprentive }\end{array}$ & Superintendencia de Compañias \\
\hline $\begin{array}{c}\text { Report of the Commil } \\
\text { External Audit Report, if, based on the total amount } \\
\text { of assets from the previous year, they are obliged to } \\
\text { contract it }\end{array}$ & Superintendencia de Compañias \\
\hline
\end{tabular}

\section{Source: Own elaboration}

In this context, although the SME may consider the internationalization process as an optimal growth strategy, this becomes unattainable when faced with an institutional environment that, among other things, produces a costly legal system (Méndez, 2018, p. 36). It is so with a high tax burden and unattractive to foreign investment, so it is very likely that the resources that 
should be used to cover the cost of training human resources, investment in research and development, or investment in the establishment of a cooperation agreement or other means of internationalization, will have to be allocated to meeting the obligations imposed by the institutional environment. Precisely, for Ghersi (2014), the cost of legality is an essential constraint for SMEs, both for their internal and external development.

Ghersi (2014) explains that when the law is costly, i.e., the cost of complying with it exceeds the benefit, both for individuals and societies, it is more convenient if that law is violated than if it is complied with, i.e., we are complying with an economically inefficient law. It is worth mentioning that an inefficient economic and legal system raises transaction costs and makes it impossible for small and medium-sized entrepreneurs to manage appropriately. In response to this, Ghersi (2014) and Méndez (2019) suggest that countries should strive for a legal system that minimizes their costs and allows the production factors to organize themselves freely and rationally.

Finally, it is worth mentioning that the "importance of the institutional context on organizations and its consequences" (Restrepo \& Rosero, 2002, p. 107) is evident, and therefore the existence of a direct influence relationship of the institutional context on the determinants of the internationalization process, as it is unavoidable not to consider that there are "institutional demands that may conflict with organizational interests and expectations" (Restrepo and Rosero 2002, p. 108), which is why an efficient institutional environment that seeks to design public policies in line with the objective of economic growth through SME internationalization is so necessary.

\section{Conclusions}

The article results indicate that the environment under which small and medium-sized enterprises operate influences every area of their performance, including pursuing growth through internationalization.

This assertion can be seen in the examples given concerning SMEs' cases that achieved a successful internationalization process supported by a favorable environment for this purpose.

Consequently, we can conclude that countries' economic growth is subordinated to the environment's conditions; if these conditions are favorable, economic growth and internationalization processes will maintain a desirable progress rate. Otherwise, the opposite effect arises, i.e., low internationalization levels, as is the case in the Ecuadorian economy.

Therefore, within the framework of SME internationalization, a robust and coordinated institutional apparatus is required, which, through its clear rules, provides regulatory guidelines but also facilitates the achievement of high levels of commercialization and, in the best of cases, the production of Ecuadorian products and services in foreign markets.

If there are variable rules, the behaviour of economic factors such as SMEs will remain individualized in response to the mistrust generated by volatile government actions, which will consequently be reflected in mediocre results. 


\section{References}

Alonso, J. (2012). Calidad institucional y entorno empresarial. Mediterráneo Económico, (21), 65-78.

Alonso, J., \& Garcimartín, C. (2008). Acción colectiva y desarrollo: El papel de las instituciones. Editorial Complutense S. A.

Amal, M., and Rocha, A. (2010). Internationalization of small and medium-sized enterprises: a multi-case study. European Business Review, 22(6), 608-623. http://doi.org/10.1108/09555341011082916

Aoki, M. (2001). Toward a Comparative Institutional Analysis. MIT Press.

Araque Jaramillo, W., \& Argüello Salazar, A. (2015). Caracterización del proceso de internacionalización de las PyME ecuatorianas. FAEDPYME International Review, 4(7), 35-46. https://doi.org/10.15558/fir.v4i7.103

Barnir, A., Gallaugher, J., and Auger, P. (2003). Business process digitization, strategy, and the impact of firm age and size: the case of the magazine publishing industry. Journal of Business Venturing, 18(6), 789-814. https://doi.org/10.1016/So883-9026(03)00030-2

Baumol, W. (1990). Entrepreneurship: Productive, unproductive, and destructive. Journal of Political Economy, 18(5), 893-921. https://www.jstor.org/stable/2937617

Bellini, E., Toscana, L., Villarreal, F., \& Klappenbach, G. (2015). Tecnología e Innovación en las PyMEs Industriales con Expectativa Exportadora. Escritos Contables Y De Administración, 2(2), 87-98. https:// doi.org/10.52292/j.eca.2011.293

Benavides, L. \& Bolaños, S. (2020). Barreras de innovación en pymes: una aproximación a través de una revisión sistemática de literatura. Tendencias, Revista de la Facultad de Ciencias Económicas y Administrativas, XXI(1), 221-237. https://doi.org/10.22267/rtend.202101.134

Bernard, A., Jensen, B., Redding, S. and Schott, P. (2012). The Empirics of Firm Heterogeneity and International Trade. Annual Review of Economics, 4, 283-313. https://www.annualreviews.org/doi/abs/10.1146/annureveconomics-080511-110928

Bianchi, P., and Miller, L. (1994). Innovation, collective action and endogenous growth: an essay on institutions and structural change. Università degli Studi di Bologna.

Blasco, J., and Pérez, J. (2007). Research methodologies in physical activity and sport sciences: Broadening horizons. University Club.

Botello, H. (2014). Conditions and determinants of the internationalization of Latin American industrial firms. Apuntes, 41(75), 47-78. https://doi.org/10.21678/apuntes.75.716

Cando, A., López, L., \& Zambrano, T. (2019). Valoración del capital intelectual: Análisis del capital humano en las PYMEs del Ecuador. Revista Inclusiones, 6, 475-491. https://revistainclusiones.org/index.php/ inclu/article/view/2176

Camagni, R. (1991). Innovation networks: spatial perspectives. Belhaven Press.

Cambra, J., \& Vázquez, R. (2010). Inés Rosales: El reto de internacionalizar la actividad de una PYME es posible. UCJC Business and Society Review, 4(28), 62-70. https://journals.ucjc.edu/ubr/article/view/763

Campins, M. (2015). Modalidades de internacionalización de dos empresas farmacéuticas argentinas en perspectiva histórica. Los casos Bagó y Sidus. Apuntes, 42(76), 95-103. https://doi.org/10.21678/ apuntes.76.730

Cantarero, S. \& Puig, F. (2013). Caracterización de las nuevas empresas internacionales de los sectores manufactureros tradicionales. Contabilidad y Negocios, 8(15), 33-42. https://revistas.pucp.edu.pe/index. php/contabilidadyNegocios/article/view/6765

Delgadillo de Lira, L. (2004). La internacionalización de las empresas familiares españolas en México: análisis de sus factores determinantes. Documentos de Trabajo Nebrija. Serie Módulo Europeo Jean Monnet. https://dialnet.unirioja.es/servlet/articulo?codigo $=1395787$

Business Intelligence Directorate. (2019). Analysis of Ecuadorian non-oil exports: July 2019. Ministerio De Producción, Comercio Exterior, Inversiones y Pesca https://n9.cl/4pq7g

El Telégrafo. (2019, octubre 14). $25 \%$ of SME exports go to the US. El Telégrafo. https://ng.cl/2hoxs 
Escolano, C., \& Belso, J. (2003). Internacionalización y PYMES: conclusiones para la actuación pública a partir de un análisis multivariante. Revista Asturiana de Economía, (27), 169-195. http://www. revistaasturianadeeconomia.org/raepdf/27/ESCOLANO.pdf

Escorsa, P., \& Valls, J. (2003). Tecnología e innovación en la empresa. Ediciones UPC.

Esteve, S., and Rodríguez, D. (2014). La innovación como factor de competitividad de las pymes. Revista de Economía, 1(877), 115-130. http://www.revistasice.com/index.php/ICE/article/view/1674

Estrella, A., Jiménez, D., Ruiz, J., and Sánchez, M. (2012). How do SMEs compete in international markets? Analysis of a local cluster with exporting vocation. European Research in Management and Business Economics, 18(1), 87-99. https://www.redalyc.org/pdf/2741/274122833005.pdf

Evans, P. (1995). Embedded autonomy: States and Industrial Transformation. Princeton University Press.

Finchelstein, D. (2013). State and firm internationalization: the cases of Argentina, Brazil and Chile. Economic Development, 53(209), 113-142. https://www.jstor.org/stable/43748225

Gabrielsson, M., Manek, V., Dimitratos, P., Solberg, C. and Zucchella, A. (2008). Born globals: Propositions to help advance the theory. International Business Review, 17(4), 385-401. https://doi.org/10.1016/j. ibusrev.2008.02.015

Gandoy, R., Díaz, C., \& Córcoles, D. (2014). Una vía de internacionalización para las pymes más capaces: la inserción en redes de producción. Información Comercial Española, (878), 131-148.

Ghersi, E. (2014, febrero 24). El mercado informal desde el análisis económico del derecho. [Youtube]. https:// youtu.be/jBOYCoHlofE

Hernández, R., Fernández, C. \& Baptista, P. (2010). Metodología de la investigación. McGraw-Hill.

Instituto Nacional de Estadística y Censos INEC. (2020, October 1). Ecuador in figures. https://cutt.ly/yRFKcna

Jaime, F., Dufour, G., Alessandro, M., and Amaya, P. (2013). Introduction to Public Policy Analysis. Universidad Nacional Arturo Jauretche.

Kalantaridis, C. (2004). Internationalization, Strategic Behavior, and the Small Firm: A Comparative Investigation. Journal of Small Business Management, 42(3), 245-262. https://doi.org/10.1111/j.1540627X.2004.00110.X

Krause, M. (2019). Institutional Quality Index 2019. Fundación Libertad y Progreso.

Krause, M. (2020). Institutional Quality Index 2020. Fundación Libertad y Progreso.

Lawson, B. and Samson, D. (2001). Developing Innovation Capability in Organization. International Journal of Innovation Management, 5(3), 1-23. https://doi.org/10.1142/S1363919601000427

León, J. (2008). Determinantes del proceso de internacionalización de las pymes peruanas: el caso del sector de la confección. Economía y Sociedad, 69, 46-57.

Majocchi, A., and Zucchella, A. (2003). Internationalization and performance: findings from a set of Italian SMEs. International Small Business Journal, 21(3), 249-268. https://doi.org/10.1177/2F02662426030213001

Manolova,T.,Brush,C.,Edelman, L. and Greene,P.(2002).Internationalization of Small Firms: Personal Factors Revisited. International Small Business Journal, 20(1), 9-31. https://doi.org/10.1177/0266242602201003

Méndez, R. and Sumar, O (2020). Rule of Law versus Soft Rule of Law. Revista de Derecho, (109), 373-400. https://doi.org/10.5944/rdp.109.2020.29065

Méndez, R. (2019). Law \& Economics. Institutional Coordination and Legal Theory. Centro de Publicaciones PUCE.

Merino, F., Prats, M., \& Pablo, F. (2017). La actividad innovadora de las PYME españolas en un contexto de recesión. Revista Espacios, 38(47), 23-42.

Mesa, R. \& Pérez, S. (2011). Desempeño exportador de Antioquia y marco institucional para su desarrollo: el papel de la Mipyme. Perfil de Coyuntura Económica, (17). 123-139 https://revistas.udea.edu.co/index. php/coyuntura/article/view/11512

Mínguez, R. (2010). La cooperación para la internacionalización como estrategia de expansión exterior de las PYME. Economía Industrial, (375), 113-124

Moori, V., Yoguel, G. \& Milesi, D. (2001). Las PYMEs exportadoras argentinas exitosas: hacia la construcción de ventajas competitivas. Editorial Miño y Dávila. 
North, D. (1990). Institutions, institutional change and economic performance. Cambridge University Press.

Olivares, A. (2005). La globalización y la internacionalización de la empresa: ¿Es necesario un nuevo paradigma? Estudios Gerenciales, (96), 127-137. https://www.icesi.edu.co/revistas/index.php/estudios_ gerenciales/article/view/167

Poblete, C. and Amorós, J. (2013). Determinantes en la Estrategia de Internacionalización para las Pymes: el Caso de Chile. Journal of Technology Management \& Innovation, 8(1), 97-106. https://doi.org/10.4067/ So718-27242013000100010

Restrepo, M. \& Rosero, X. (2002). Teoría institucional y proceso de internacionalización de las empresas colombianas. Estudios Gerenciales, 18(84). 103-126 https://www.icesi.edu.co/revistas/index.php/ estudios_gerenciales/article/view/89

Rojas, S. \& Vega, R. (2013). Los procesos de internacionalización en las PYMES: una reflexión desde diferentes perspectivas. Poliantea, 9(16), 53-70.

Tabares, S. (2012). Revisión analítica de los procesos de Internacionalización de las PYMES. Pensamiento \& Gestión, (33). https://rcientificas.uninorte.edu.co/index.php/pensamiento/article/view/4897

Vargas, J., Martínez, M., and Mojica, E. (2011). Influencia de la orientaciòn al mercado y la innovaciòn en la internacionalización y el desempeño de las pymes en el Estado de Aguascalientes. Revista da Micro e Pequeña Empresa, 5(1), 120-133. https://doi.org/10.6034/163

Virginia, M., Yoguel, G. \& Milesi, D. (2001). Las PYMEs exportadoras argentinas exitosas: hacia la construcción de ventajas competitivas. Editorial Miño y Dávila.

Yoguel, G. (1998). Development of the learning process of firms: local spaces and productive plots. The National University of General Sarmiento.

Yoguel, G. \& Boscherini, F. (1996). La capacidad innovativa y el fortalecimiento de la competitividad de las firmas: el caso de las PYMEs exportadoras argentinas. CEPAL.

\section{AUTHORS}

Rubén Méndez Reátegui. Professor at the Pontificia Universidad Católica del Ecuador - PUCE, Ecuador. Research project academically supported by the Programa de Postdoctorado América Latina en el Orden Global, Colegio de América Sede Latinoamericana, Universidad Andina Simon Bolívar.

Fernanda Macías Mero. Member of Grupo de Investigación en Derecho Económico at the Pontificia Universidad Católica del Ecuador. 